\title{
REVIEW
}

\section{The role of Smad7 in oral mucositis}

\author{
Li Bian ${ }^{1,2}$, Gangwen Han $^{2,3}$, Carolyn W. Zhao², Pamela J. Garl' ${ }^{2}$ Xiao-Jing Wang ${ }^{2 \bowtie}$ \\ ${ }^{1}$ Department of Pathology, The First Affiliated Hospital of Kunming Medical University, Kunming 650032, China \\ 2 Department of Pathology, University of Colorado Anschutz Medical Campus, Aurora, CO 80203, USA \\ ${ }^{3}$ Department of Dermatology, The Second Hospital of Shandong University, Jinan 250033, China \\ $\triangle$ Correspondence: xj.wang@ucdenver.edu (X.-J. Wang) \\ Received November 17, 2014 Accepted December 12, 2014
}

\begin{abstract}
Oral mucositis, a severe oral ulceration, is a common toxic effect of radio- or chemoradio-therapy and a limiting factor to using the maximum dose of radiation for effective cancer treatment. Among cancer patients, at least $40 \%$ and up to $70 \%$, of individuals treated with standard chemotherapy regimens or upper-body radiation, develop oral mucositis. To date, there is no FDA approved drug to treat oral mucositis in cancer patients. The key challenges for oral mucositis treatment are to repair and protect ulcerated oral mucosa without promoting cancer cell growth. Oral mucositis is the result of complex, multifaceted pathobiology, involving a series of signaling pathways and a chain of interactions between the epithelium and submucosa. Among those pathways and interactions, the activation of nuclear factor-kappa B (NF-KB) is critical to the inflammation process of oral mucositis. We recently found that activation of TGF $\beta$ (transforming growth factor $\beta$ ) signaling is associated with the development of oral mucositis. Smad7, the negative regulator of TGF $\beta$ signaling, inhibits both NF-KB and TGF $\beta$ activation and thus plays a pivotal role in the prevention and treatment of oral mucositis by attenuating growth inhibition, apoptosis, and inflammation while promoting epithelial migration. The major objective of this review is to evaluate the known functions of Smad7, with a particular focus on its molecular mechanisms and its function in blocking multiple pathological processes in oral mucositis.
\end{abstract}

\section{KEYWORDS Smad7, oral mucositis, cancer, TGF $\beta$, NF-KB}

\section{ORAL MUCOSITIS FREQUENCY}

Oral mucositis, a severe oral ulceration, is a common toxic effect of radiation for bone marrow transplant and upper body radiotherapy or chemo-radiotherapy for all cancer types (Sonis, 2010; Vagliano et al., 2011). Severe oral mucositis is extremely painful and impairs food/liquid intake, and is rated by patients as the most debilitating side effect of cancer therapy (Bellm et al., 2000). At least $40 \%$, and up to $70 \%$, of individuals treated with standard chemotherapy regimens or upper-body radiation develop oral mucositis (Scully et al., 2003). Among them, over $80 \%$ of oral cancer patients (the 6 th most common cancer worldwide) are treated with radiation and at least $70 \%$ develop severe oral mucositis (Trotti et al., 2003; Vera-Llonch et al., 2006). The use of intensity modulated radiotherapy (IMRT) spares more normal tissue and lessens chronic side effects, but does not alleviate the acute toxicity seen in oral mucosa (Khuntia D et al., 2008) and certain patients are at a high risk of oral mucositis regardless of treatment regimen (Scully et al., 2006). Further, many high risk patients experience amplified acute oral mucositis when receiving radiotherapy combined with targeted therapies (Sonis, 2013). In the US, there are at least one million oral mucositis patients every year. Costs to care for oral mucositis can be up to $\$ 6,000$ per patient per chemo- or radiation cycle for narcotic therapy, antibiotics, anemia, liquid diet, additional office visits, and nursing staff costs. For more severe oral mucositis cases, when a feeding tube and additional hospitalization are needed, the cost of associated care can be up to $\$ 25,000 /$ cycle. Because there is no effective treatment, oral mucositis lesions are often serious enough to delay, reduce or halt cancer therapy. Palifermin, a human keratinocyte growth factor (KGF) recombinant protein, is the only FDA approved targeted therapy for preventing oral mucositis in bone-marrow transplant patients ( $4 \%$ of the at-risk population), but it has no effect on existing mucositis (Sonis, 2010). Palifermin clinical trials in head and neck cancer patients showed only modest preventive effects on severe oral mucositis incidence (Henke et al., 2011; Le et al., 2011). The incidence and severity of mucositis depends on multiple factors, including chemotherapeutic agents and 
doses, radiation regimen, patient age, gender, nutritional status, oral microbiota, salivary secretory function, and genetic variation (Barasch and Peterson, 2003; Sonis, 2009).

\section{PATHOLOGICAL PROCESSES OF ORAL MUCOSITIS}

Oral mucositis is characterized by an infiltration of excessive inflammatory cells, epithelial ablation, and ulcer development (Scully et al., 2006; Wu et al., 2010). Oral mucositis consists of five overlapping stages: initiation, damage response, signal amplification, ulceration, and healing. At the initiation stage, radiotherapy or chemotherapy injures the tissue through DNA strand breaks, cell death in the basal and suprabasal layers, and halting epithelial proliferation. Additionally, the injured tissue produces reactive oxygen species (ROS), which in turn induce oxidative stress-associated DNA damage. Apart from the epithelial injury, radiotherapy and chemotherapy also exacerbate the mucosal damage by effecting the underlying submucosa, including endothelia, fibroblasts, and leukocytes (Treister and Sonis; Denham and Hauer-Jensen, 2002; Sonis, 2004a; Lalla and Peterson, 2006). During the damage response stage, submucosal cells expressing early response genes, such as c-jun, c-fos, and Erg-1, join in the intricate series of biological cascades, and several signal transduction pathways are activated. Among them, NF-KB is one of the most significantly activated pathways, which upregulates many genes to elicit a wide range of tissue responses and affect the process of oral mucositis (Sonis, 2002; Sonis, 2004a). At the signaling amplification stage, pro-inflammatory cytokines such as NF-kB, tumor-necrosis factor- $\alpha$ (TNF- $\alpha$ ), interleukin- $1 \beta$ (IL-1 $\beta$ ), interleukin-6 (IL-6), ceramide, and matrix metalloproteinases (MMPs), are overproduced. Mucosal damage triggers the initial release of these factors, leading to the positive feedback loop that amplifies mucosal damage (Sonis, 2002; Sonis, 2004a). At the ulceration stage, the integrity of the epithelium disintegrates and ulceration occurs with a massive infiltration of leukocytes in response to both tissue injury and secondary microbial infection. (Treister and Sonis; Sonis, 2004a). Subsequently, tissue begins to heal. In the healing stage, the epithelium is re-epithelialized by migrating keratinocytes followed by keratinocyte proliferation to restore normal epithelial layers that are remodeled by differentiation. Inflammation is reduced, and stromal fibroblasts as well as vessels are remodeled (Treister and Sonis; Sonis, 2004a).

\section{ORAL MUCOSITIS CARE AND EXPERIMENTAL THERAPEUTICS}

Due to the complex and multifaceted pathobiology of oral mucositis (Sonis, 2004b), diverse interventions have been tested (Lalla et al., 2014). Based on these studies, the Multinational Association of Supportive Care in Cancer/ National Society of Oral Oncology (MASCC/ISOO) recently revised evidence-based clinical practice guidelines for oral mucositis care (Table 1). In general, oral mucositis care involves basic oral care and control of symptoms through the use of antimicrobials, coating agents, anesthetics, and analgesics. Oral mucositis interventions are focused on growth factors and anti-inflammatory agents (Lalla et al., 2014). Although several growth factors, such as KGF (Henke et al., 2011; Le, 2011; Weigelt et al., 2011), epidermal growth factor (EGF) (Epstein et al., 2000; Wu et al., 2009), and granulocyte-colony-stimulating factor (G-CSF) (Jyung et al., 1994; Raber-Durlacher et al., 2013) have been explored for oral mucositis treatment, Palifermin (truncated KGF) is the only US FDA approved drug recommended by MASCC/ ISOO for oral mucositis prevention (Spielberger et al., 2004; Raber-Durlacher et al., 2013). The major concern when using a growth factor to treat oral mucositis is the potential oncogenic effect that would compromise cancer treatment. Among studied anti-inflammatory agents, benzydamine is an effective antioxidant, anti-inflammatory agent, and inhibitor of leukocyte-endothelial interactions (Epstein et al., 2001), also having analgesic, anesthetic, and antimicrobial activities (Rubenstein et al., 2004). Therefore, the MASCC/ISOO guidelines recommend benzydamine mouthwash for the prevention of radiation-induced mucositis in patients with head and neck cancer receiving moderate dose radiotherapy (Nicolatou-Galitis et al., 2013). However, not all anti-inflammatory agents are effective at alleviating oral mucositis (Lalla et al., 2014).

In addition to therapeutic agents, laser or other light therapy and cryotherapy have also been explored for oral mucositis prevention. Low-level laser therapy has been shown to have photochemical, photophysical, and photobiological effects on cellular metabolism (Migliorati, 2013). Cryotherapy causes vasoconstriction and decreases blood flow to the oral cavity, reducing exposure of the buccal mucosa to chemotherapy (Sorensen et al., 2008). However, its usefulness is limited to only a few chemotherapeutics with short half-lives (Peterson et al., 2013). Further, a large number of natural agents have been explored for oral mucositis treatment (Lalla et al., 2014). Among them, zinc, an essential trace element for some tissue repair processes with antioxidant effects (Yarom et al., 2013), is the only one suggested by the MASCC/ISOO for oral mucositis prevention (Lalla et al., 2014). Overall, among the MASCC/ISOO recommended/suggested therapies, each primarily targets one of the pathological processes of oral mucositis and thus is only moderately effective. This situation highlights the need for a new therapeutic strategy.

\section{ROLE OF TGF $\beta$ SIGNALING IN INFLAMMATION AND ORAL MUCOSITIS}

TGF $\beta$ has three isoforms and TGF $\beta 1$ is the predominant form in keratinocytes (Pittelkow et al., 1988). TGF $\beta$ signals through type I and type II receptors that have serine/ 
TABLE 1. MASCC/ISOO clinical practice guidelines for care of patients with oral mucositis

\begin{tabular}{|c|c|c|c|}
\hline Intervention & Purpose & Treatment category/patient population & Guideline \\
\hline \multicolumn{4}{|l|}{ Basic oral care } \\
\hline Oral care & Prevention & All patients & Suggested \\
\hline Chlorhexidine mouthwash & Prevention & Radiotherapy for HNC & Suggested \\
\hline \multicolumn{4}{|l|}{ Cytokines and growth factors } \\
\hline Palifermin (truncated KGF) & Prevention & $\begin{array}{l}\text { High-dose chemotherapy and total body } \\
\text { irradiation followed by autologous stem cell } \\
\text { transplantation for a hematological malignancy }\end{array}$ & Recommended \\
\hline \multicolumn{4}{|l|}{ Anti-inflammatory agents } \\
\hline Benzydamine mouthwash & Prevention & $\begin{array}{l}\text { Moderate dose radiation therapy (up to } 50 \mathrm{~Gy} \text { ), } \\
\text { without concomitant chemotherapy in patients } \\
\text { with HNC }\end{array}$ & Recommended \\
\hline \multicolumn{4}{|c|}{ Antimicrobials, coating agents, anesthetics, and analgesics } \\
\hline Patient-controlled analgesia with morphine & Treat pain & HSCT & Recommended \\
\hline Transdermal fentanyl & Treat pain & $\begin{array}{l}\text { Conventional or high-dose chemotherapy, with } \\
\text { or without total body irradiation }\end{array}$ & Suggested \\
\hline $2 \%$ morphine mouthwash & Treat pain & Radiotherapy for HNC & Suggested \\
\hline $0.5 \%$ doxepin mouthwash & Treat pain & Radiotherapy for HNC & Suggested \\
\hline \multicolumn{4}{|l|}{ Device directed therapies } \\
\hline Low-level laser (wavelength at $650 \mathrm{~nm}$ ) & Prevention & $\begin{array}{l}\text { HSCT conditioned with high-dose } \\
\text { chemotherapy, with or without total body } \\
\text { irradiation }\end{array}$ & Recommended \\
\hline Low-level laser (wavelength 632.8 nm) & Prevention & H\&N RT without concomitant chemotherapy & Suggested \\
\hline Cryotherapy & Prevention & $\begin{array}{l}\text { Bolus } 5 \text {-fluorouracil chemotherapy } \\
\text { High-dose melphalan, with or without total body } \\
\text { irradiation, as conditioning for HSCT }\end{array}$ & $\begin{array}{l}\text { Recommended } \\
\text { Suggested }\end{array}$ \\
\hline \multicolumn{4}{|l|}{ Natural and miscellaneous agents } \\
\hline Zinc supplements & Prevention & $\begin{array}{l}\text { Radiotherapy or chemoradiotherapy for oral } \\
\text { cancer }\end{array}$ & Suggested \\
\hline
\end{tabular}

Abbreviations: Gy, grays; HSCT, hematopoietic stem cell transplantation; MASCC/ISOO, Multinational Association of Supportive Care in Cancer and International Society of Oral Oncology; KGF, Keratinocyte growth factor; head and neck radiation therapy (H\&N RT) head and neck cancer (HNC).

threonine kinase activities and downstream Smad proteins, specifically Smad2 and Smad3 (Fig. 1) (Massague and Gomis, 2006). After ligand binding, the type I receptor phosphorylates Smad2 and Smad3, which then bind to Smad4, forming a trimeric complex that translocates from the cytoplasm into the nucleus. The trimeric Smad complex binds to Smad binding elements (SBEs) to regulate gene expression (Feng and Derynck, 2005; Groneberg et al., 2004).

TGF $\beta 1$ was initially identified as an immunosuppressive, anti-inflammatory molecule (Shull et al., 1992; Kulkarni et al., 1993). TGF $\beta 1$-deficient mice exhibit inflammation in multiple organs, succumbing to multifocal inflammation and autoimmune disorders in the internal organs (Shull et al., 1992; Kulkarni et al., 1993). However, TGF $\beta 1$ also has a proinflammatory effect. Levels of TGF $\beta 1$ increase rapidly following injury due to secretion by keratinocytes, platelets, and macrophages (Singer and Clark, 1999), and increased levels of TGF $\beta 1$ rapidly recruit leukocytes to accumulate at the injury site. Infiltrated leukocytes secrete chemokines and inflammatory cytokines stimulating the inflammatory response (Wang et al., 2006). The pro-inflammatory effect of TGF $\beta 1$ is further substantiated in K5.TGF $\beta 1$ transgenic mice with latent human TGF $\beta 1$ overexpression in the skin and oral mucosa (Li et al., 2004a; Lu et al., 2004), where severe inflammation is observed.

Our recent study identified increased TGF $\beta$ protein and signaling activities in both human oral mucositis lesions and radiation-induced oral mucositis in mice (Han et al., 2013). Because TGF $\beta$ is a potent epithelial cell growth inhibitor, activated TGF $\beta$ induces growth arrest of irradiated epithelial cells. Arresting these cells could allow them to repair damaged DNA, but severe growth arrest also contributes to the thinning of epithelial layers and progression to an ulcer. 


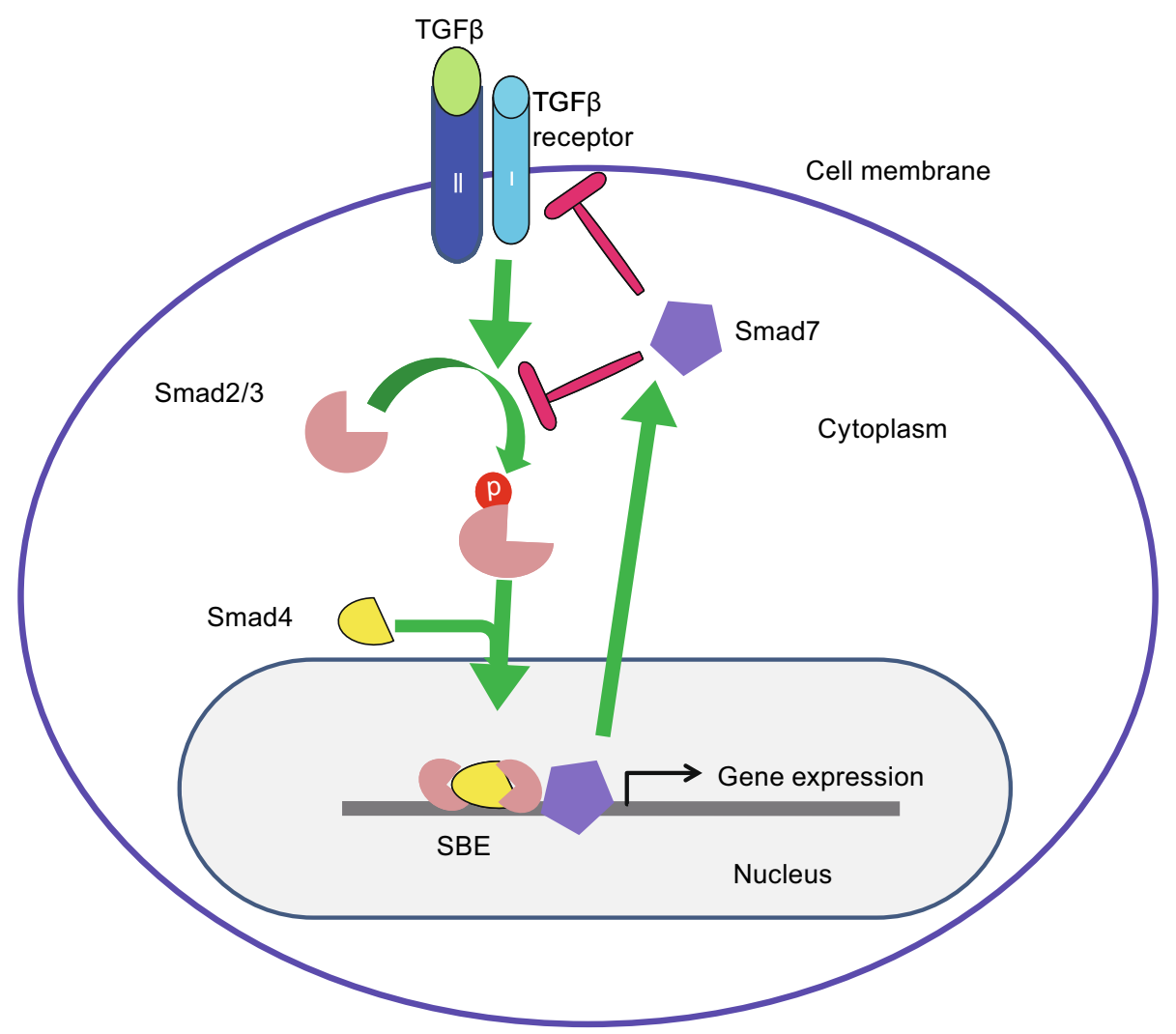

Figure 1. TGF $\beta$ signaling components. TGF $\beta$ signals through type I and type II receptors when TGF $\beta$ ligand binds to the type II receptor. The serine/threonine kinase of the type I receptor phosphorylates Smad2 and Smad3, which then bind to Smad4, forming a trimeric complex that translocates from the cytoplasm into the nucleus. The trimeric Smad complex binds to Smad binding elements (SBEs) to regulate gene expression. Smad7 is a nuclear protein. It competes with signaling Smads on SBEs, and translocates to the cytoplasm to block phosphorylation of Smad2/3 or induce degradation of TGFßRI and Smad2/3.

Additionally, TGF $\beta$ induces apoptosis, potentially contributing greatly to the massive cell death found in oral mucositis. Further, our previous study showed that TGF $\beta 1$ activates NF-KB (Li et al., 2004b) and elicits severe inflammation in oral mucosa (Lu et al., 2004). Excessive inflammation in oral mucositis could therefore be largely due to TGF $\beta$ overexpression. Our study suggests that TGF $\beta$ contributes to multiple pathological processes responsible for oral mucositis development. Further, our previous study has shown that excessive and prolonged TGF $\beta 1$ expression in keratinocytes resulted in delayed wound healing (Wang et al., 2006). Therefore, increased TGF $\beta$ in oral mucositis would also delay its healing.

\section{SMAD7: A TGF $\beta$ SIGNALING ANTAGONIST AND CROSS-TALK MEDIATOR OF MULTIPLE PATHWAYS IN DISEASES}

Smad7, a nuclear protein, was initially identified to block TGF $\beta$ signaling through translocation to the cytoplasm to block phosphorylation of Smad2/3 (Hayashi et al., 1997;
Nakao et al., 1997; Nakao et al.,2002). Later, Smad7 was found to recruit E3 ubiquitin ligases (Smurf1 and Smurf2) to degrade TGF $\beta R I$ and Smad2/3 (Kavsak et al., 2000; Lin et al., 2000; Ebisawa et al., 2001). Smad7 also binds to DNA through its $\mathrm{MH} 2$ domain to regulate transcription (Yan and Chen, 2011).

Because TGF $\beta$ is a potent growth inhibitor for epithelial cells and induces apoptosis in many cell types, Smad7 promotes cell proliferation and survival once it reaches a level sufficient to block TGF $\beta$ signaling ( $\mathrm{He}$ et al., 2002; Han et al., 2011). These functions of Smad7 contribute greatly to its role in promoting wound healing after injuries, when cell proliferation is required (Mallawaarachchi et al., 2005; Saika et al., 2005; Han et al., 2011). Additionally, Smad7 promotes cell migration, required for normal wound healing, through interactions with other pathways. Specifically, Smad7 promotes the MAPK3-p38 complex formation to activate JNK/p38 (Edlund et al., 2003), activates Erk (Han et al., 2011), and recruits adenomatous polyposis coli (APC) to the microtubule (Ekman et al., 2012). 
Smad7 is expressed at exceedingly low levels in normal keratinocytes (He et al., 2001), but is often overexpressed under pathological conditions (He et al., 2002; Han et al., 2011). Inflammatory diseases frequently show elevated TGF $\beta$-induced levels of Smad7 expression. Because TGF $\beta$ in the skin and oral mucosa primarily functions as a proinflammatory cytokine, the anti-TGF $\beta$ effect of Smad7 makes it act as an anti-inflammatory molecule. Further, Smad7 directly antagonizes NF-kB, the major inflammation pathway. Smad7 overexpression up-regulates IKBa expression, an NF-kB inhibitor (Wang et al., 2005). Smad7 also disrupts the formation of the protein complex TRAF2/TAK1/TAB2/TAB3 (TNF-receptor associated factor 2/TGF $\beta$-activated kinase 1/TAK-binding protein 2/3), which is essential for activation of the inflammation cascade (Hong et al., 2007). Therefore, the anti-TGF $\beta$ and anti-NF-kB activities of Smad7 make it one of the most potent anti-inflammatory molecules in stratified epithelial tissues. Similarly, Smad7 knockout mice developed kidney inflammation (Chung et al., 2009; Chen et al., 2011). In contrast, because TGF $\beta$ is a potent immune suppressant in the gut, high levels of Smad7 expression in the gut cause inflammatory bowel disease (IBD) due to the loss of TGF $\beta$ responsiveness (Monteleone et al., 2004).

With respect to the role of Smad7 in tumorigenesis, because TGF $\beta$ is a potent growth inhibitor and apoptosis inducer, the anti-TGF $\beta$ effect of Smad7 is suspected to promote tumor growth and survival. In support of this notion, Smad7 overexpression is associated with poor prognosis in colorectal cancer (Boulay et al., 2001). In experimental models, overexpression of Smad7 can promote malignant transformation and tumorigenicity in the pancreas, gastric, lung, skin, and colon (Kim et al., 2004; Kleeff et al., 1999; Liu et al., 2003; Halder et al., 2005; Luo et al., 2010). In contrast, Smad7 has been shown to inhibit cancer progression and metastasis in many tumor types in experimental models, including melanoma, breast cancer colorectal cancer, head and neck and liver cancers in vitro and in vivo (Azuma et al., 2005; Javelaud et al., 2005; Leivonen et al., 2006; Rizzo et al., 2011; Wang et al., 2013). Smad7's anti-inflammatory effect in certain tissues and induction of apoptosis in certain cancer types (Wang et al., 2013) could contribute to its tumor-suppressive effect. Additionally, because TGF $\beta$ induces formation of cancer-associated fibroblasts (CAFs) to promote cancer progression, it is not surprising that Smad7 can block this process (Li et al., 2013). Interestingly, a study demonstrated that while Smad7 overexpression in T cells increases colitis severity, it decreases colitis-associated cancer (Rizzo et al., 2011). Therefore, the enhanced immune response could also attack tumor cells, a principle for immunotherapy in cancer.

The tissue/context-specific effects of Smad7 partially explain the dual roles of Smad7 in cancer. Another explanation could be dose-dependent effects of Smad7. For instance, while high levels of Smad7 overexpression driven by adenoviral transduction cause skin tumor progression in immune compromised recipient mice (Liu et al., 2003), we have not observed spontaneous tumor formation in $\mathrm{K} 5$. Smad7 transgenic mice that express Smad7 at a modest level, even though this level of Smad7 is sufficient to block Wnt signaling (Han, et al., 2006).

\section{SMAD7: EFFECTS ON PREVENTION AND TREATMENT OF ORAL MUCOSITIS}

We utilized K5.Smad7 mice that express a Smad7 transgene in oral epithelia under the control of a keratin 5 promoter, as an animal model, to study their susceptibility to radiationinduced oral mucositis. We found that these mice are remarkably resistant to radiotherapy-induced oral mucositis. This prompted us to seek a pharmacological approach to deliver Smad7 protein into the oral cavity. Exogenous Smad7 has to be delivered inside cells to its natural cellular location, the nucleus. To this end, we developed a recombinant human Smad7 protein with an $\mathrm{N}$-terminal Tat tag (TatSmad7), permitting the proteins to rapidly permeate the cell membrane and enter into the nucleus (Han et al., 2013). To test the efficacy of Tat-Smad7 in oral mucositis prevention, we exposed mice to fractionated cranial radiation and topically applied Tat-Smad7 to the oral cavity daily starting $24 \mathrm{~h}$ before irradiation through day 8 after initiation of irradiation and observed the treated tissues on day 9. We found TatSmad7 treatment significantlly reduced ulcer incidence and sizes. Next, we tested if Tat-Smad7 can be used to treat existing oral mucositis. We began topical Tat-Smad7 application 6 days after irradiation, (when mucosal damage was obvious) applying daily to day 9 and observed the treated tissues on day 10. Tat-Smad7 treated mice show accelerated healing compared to the control group. Our studies show that the preventive and therapeutic effects of Smad7 are due to blocking multiple pathological processes of oral mucositis as discussed below.

\section{Anti-inflammatory effects of Smad7}

We found that both K5.Smad7 mice and Tat-Smad7 treated mouse oral mucosa have less inflammation than control mice during radiation-induced oral mucositis. In these tissues, pSmad2, a surrogate marker for TGF $\beta$ activation, and nuclear NF-kB p50, a surrogate marker for NF-kB activation, were both reduced by Smad7 (Han et al., 2013). Because excessive inflammation and upregulation of pro-inflammatory cytokines are early stage insults, the antagonistic effect of Smad7 on both TGF $\beta$ and NF-KB signaling substantially contributes to reduced mucositis formation when $\mathrm{Smad} 7$ is used as a therapeutic. Because inflammation further exacerbates radiation-induced tissue damage (Sonis, 2004b), reducing inflammation in pre-exisiting lesions provides a beneficial microenvironment for oral mucositis healing. These data indicate Smad7 is a more efficient anti-inflammatory molecule than other pathway inhibitors that target 
only the NF-kB pathway or the TGF $\beta$ pathway (Han et al., 2011; Han et al., 2013).

\section{Role of Smad7 in proliferation and apoptosis of epithelial cells}

In previous studies, we found that Smad7 increases proliferation but reduces apoptosis in stratified epithelia (He et al., 2002). Overexpression of Smad7 can accelerate epithelial cell proliferation and decrease levels of apoptosis, promoting wound healing by blocking TGF $\beta$ induced growth inhibition and apoptosis (Han et al., 2011; Han et al., 2013). In oral mucositis, epithelial proliferation is nearly halted due to the presumed combination of TGF $\beta$-mediated growth inhibition and DNA damage-associated cell cycle arrest after radiation. These are primary targets for the therapeutic effect of Palifermin, a potent growth factor. We found that the proliferative effect of Smad7 in oral mucositis was not as pronounced as that of Palifermin, but is sufficient to restore proliferation to a normal baseline level. Additionally, because Palifermin is given systemically via i.v. injection, all keratinocytes in the body go through hyperproliferation in response to Palifermin treatment. In contrast, Tat-Smad7 can be administered locally, avoiding stimulation of non-target cells, particularly cancer cells away from the ulcer. Because Palifermin does not fully protect cells from damage and apoptosis, hyperproliferation is needed to compensate for lost epithelial cells to prevent oral mucositis. This could explain why Palifermin needs to be administered three days before radiotherapy. In contrast, a recent study has shown that Smad7 enhances DNA repair after radiation by direct interactions with the ATM DNA repair complex (Park et al., 2014). This effect, together with its potent anti-inflammatory effect, could explain why Tat-Smad7 treated oral mucosa has fewer damaged and apoptotic cells than Palifermin-treated mucosa. Reduced DNA damage and cell death would diminish the need for hyperproliferation.

\section{Role of Smad7 in acceleration of epithelial migration}

When using Tat-Smad7 as a therapeutic agent for existing oral mucositis, its role in epithelial migration would be essential to initiate healing. During wound closure, re-epithelialization relies primarily on rapid migration of keratinocytes at the wound edge and proliferation of the basal layer of epithelial cells located adjacent to the wound site (Castilho et al., 2010; Lawson and Burridge, 2014). We found that knocking down Smad7 in normal human oral keratinocytes abrogates cell migration (Han et al., 2013). This phenomenon is strikingly comparable with loss of Rac1, a member of the Rho family of GTPases necessary for oral wound healing and keratinocyte migration (Liu et al., 2009; Castilho et al., 2010). We found that Smad7 increases expression levels and activities of Rac1 (Han et al., 2013). This finding was initially surprising because TGF $\beta$ signaling is known to activate Rac1 at the protein level via a Smad-independent mechanism (Derynck and Zhang, 2003). Further analyses revealed that Rac1 is repressed by $S$ mad2/3/4, the protein complex that recruits the transcriptional co-repressor CtBP1. This Smad-mediated Rac1 repression is abrogated when Smad7 prevents binding of Smad2/3/4 and CtBP1 to the SBE site on the Rac1 promoter. Although it remains to be determined if elevated TGF $\beta$ is able to activate Rac1 via a non-Smad pathway in the context of oral mucositis, Smaddependent Rac1 repression could overcome Smad-independent Rac1 activation. When this repression is nullified by Smad7, Rac1-mediated epithelial migration and proliferation are enabled. We also found much higher levels of endogenous Rac1 in oral cancer cells than in normal keratinocytes. In cancer cells, signaling Smads are lost or inactivated so their repression of Rac1 would be absent or other oncogenic mechanisms could independently activate Rac1. This potentially explains why Smad7 preferentially activates Rac1 and promotes migration in normal, but not cancer, epithelial cells.

\section{SUMMARY AND PERSPECTIVES}

Oral mucositis has multiple pathological processes, hence targeting one of them is insufficient for therapeutic efficacy. We found that Smad7 has both prophylactic and therapeutic effects on radiation-induced oral mucositis in mice. At the pathological level, Smad7 targets multiple pathological processes required for oral mucositis development, particularly through its effects on proliferation, apoptosis, migration in keratinocytes, and reducing inflammation in the stroma. At the molecular level, Smad7 functions in both the cytoplasm and nucleus to dampen TGF $\beta$ and NF-KB pathways and regulates targets to encourage oral mucositis healing (Fig. 2).

Considering the pleotropic effects of Smad7, future challenges to using Smad7-based therapy will be to promote wound healing without blocking TGF $\beta$-mediated tumor-suppressive effects. In most cancer types, loss of TGF $\beta$-mediated tumor suppression occurs at the molecular level for TGF $\beta$ signaling components or through other oncogenic pathways that override TGF $\beta$-induced tumor suppressive effects. In these tumors, Smad7 may not be able to affect cancer cell behavior but instead selectively affect healthy mucosa. However, TGF $\beta$ signaling is often activated in tumor stroma. Consequently, Smad7 provides tumor suppressive effects through the inhibition of TGF $\beta$ and NF-KB- mediated tumor promotion in tumor stroma (Azuma et al., 2005; Hong et al., 2007; DiVito et al., 2010). The effect of Smad7 on the stroma is consistent with the rationale for using TGF $\beta$ inhibitors to treat advanced metastatic cancers in clinical trials. Nevertheless, the dosage and time course need to be carefully assessed to minimize the risk of Smad7 treatment causing a resurgence of cancer cells. 
A

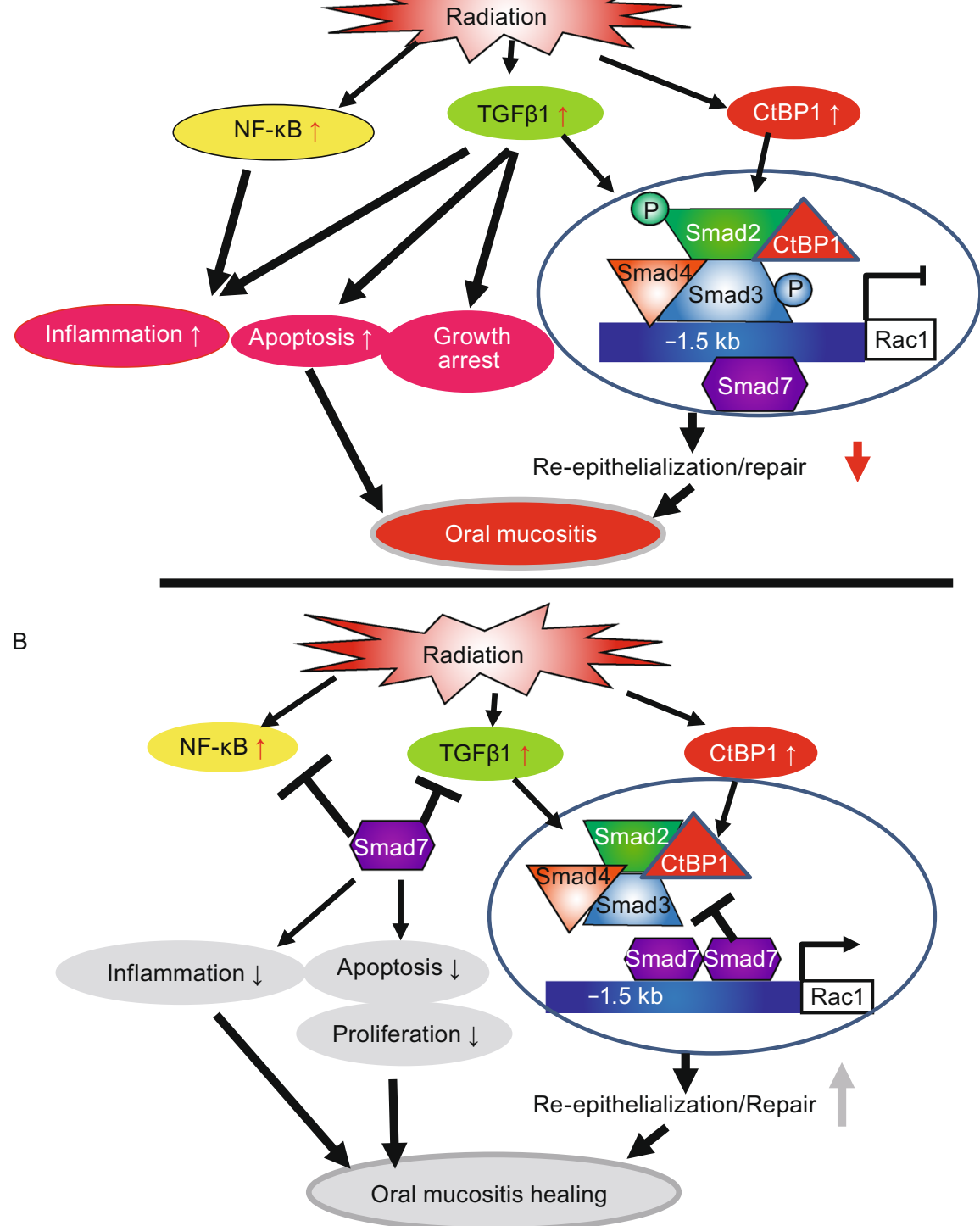

Figure 2. Summary of potential mechanisms of Smad7-mediated protection and healing of oral mucositis (from Han et al., Nature Medicine, 2013). (A) Radiation activates NF-KB, increases TGF $\beta 1$ and CtBP1. NF-KB and TGF $\beta 1$ induce inflammation. TGF $\beta 1$ induces apoptosis, growth arrest, and activates Smads which recruit CtBP1 to the Rac1 promoter to repress Rac1 transcription, leading to blunted re-epithelialization. (B) Smad7 blocks NF-KB and TGF $\beta 1$-induced inflammation and blocks TGF $\beta 1$ induced apoptosis and growth arrest. Smad7 activates Rac1 by either preventing TGF $\beta 1$-mediated Smad phosphorylation or competing with signaling Smads/CtBP1 transcriptional repression complex in the Rac1 promoter. Increased Rac1 induced by Smad7 contributes to keratinocyte migration during re-epithelialization.

\section{ACKNOWLEDGEMENTS}

We thank Wang lab members and collaborators for performing original studies related to this review. The original work was supported by NIH R01 AR61792 to Xiao-Jing Wang and a talent program for Li Bian. Li Bian is currently supported by the National Natural Science Foundation of China (Grant No. 81460355). Gangwen Han is currently supported by the National Natural Science Foundation of China (Grant No. 81472903) and startup funding from the Second
Hospital of Shandong University. Carolyn Zhao was supported by the University of Colorado Cancer Center Summer Research Program.

\section{ABBREVIATIONS}

IBD, inflammatory bowel disease; IL-1 $\beta$, interleukin-1 $\beta$; IL-6, interleukin-6; KGF, keratinocyte growth factor; MMPs, matrix metalloproteinases; NF-kB, nuclear factor-kB; ROS, reactive 
oxygen species; TGF $\beta$, transforming growth factor $\beta$; TNF- $\alpha$, tumornecrosis factor- $\alpha$.

\section{COMPLIANCE WITH ETHICS GUIDELINES}

Li Bian, Gangwen Han, Carolyn Zhao and Pamela Garl declare that they have no conflict of interest. Xiao-Jing Wang is the scientific founder of Allander Biotechnologies, LLC. This is a review of previous studies and does not contain any original studies with human or animal subjects performed by any of the authors.

\section{OPEN ACCESS}

This article is distributed under the terms of the Creative Commons Attribution License which permits any use, distribution, and reproduction in any medium, provided the original author(s) and the source are credited.

\section{REFERENCES}

Azuma H, Ehata S, Miyazaki H, Watabe T, Maruyama O, Imamura T, Sakamoto T, Kiyama S, Kiyama Y, Ubai T et al (2005) Effect of Smad7 expression on metastasis of mouse mammary carcinoma JygMC(A) cells. J Natl Cancer Inst 97:1734-1746

Barasch A, Peterson DE (2003) Risk factors for ulcerative oral mucositis in cancer patients: unanswered questions. Oral Oncol 39:91-100

Bellm LA, Epstein JB, Rose-Ped A, Martin P, Fuchs HJ (2000) Patient reports of complications of bone marrow transplantation. Support Care Cancer 8:33-39

Boulay JL, Mild G, Reuter J, Lagrange M, Terracciano L, Lowy A, Laffer U, Orth B, Metzger U, Stamm B et al (2001) Combined copy status of 18q21 genes in colorectal cancer shows frequent retention of SMAD7. Genes Chromosomes Cancer 31:240-247

Castilho RM, Squarize CH, Leelahavanichkul K, Zheng Y, Bugge T, Gutkind JS (2010) Rac1 is required for epithelial stem cell function during dermal and oral mucosal wound healing but not for tissue homeostasis in mice. PLoS One 5:e10503

Chen HY, Huang XR, Wang W, Li JH, Heuchel RL, Chung AC, Lan HY (2011) The protective role of Smad7 in diabetic kidney disease: mechanism and therapeutic potential. Diabetes 60:590-601

Chung AC, Huang XR, Zhou L, Heuchel R, Lai KN, Lan HY (2009) Disruption of the Smad7 gene promotes renal fibrosis and inflammation in unilateral ureteral obstruction (UUO) in mice. Nephrol Dial Transplant 24:1443-1454

Denham JW, Hauer-Jensen M (2002) The radiotherapeutic injury-a complex 'wound'. Radiother Oncol 63:129-145

Derynck R, Zhang YE (2003) Smad-dependent and Smad-independent pathways in TGF-beta family signalling. Nature 425:577-584

DiVito KA, Trabosh VA, Chen YS, Chen Y, Albanese C, Javelaud D, Mauviel A, Simbulan-Rosenthal CM, Rosenthal DS (2010) Smad7 restricts melanoma invasion by restoring $\mathrm{N}$-cadherin expression and establishing heterotypic cell-cell interactions in vivo. Pigment Cell Melanoma Res 23:795-808

Ebisawa T, Fukuchi M, Murakami G, Chiba T, Tanaka K, Imamura T, Miyazono K (2001) Smurf1 interacts with transforming growth factor-beta type I receptor through Smad7 and induces receptor degradation. J Biol Chem 276:12477-12480

Edlund S, Bu S, Schuster N, Aspenstrom P, Heuchel R, Heldin NE, ten Dijke P, Heldin CH, Landstrom M (2003) Transforming growth factor beta1-induced apoptosis of prostate cancer cells involves Smad7-dependent activation of p38 by TGF-beta-activated kinase 1 and mitogen-activated protein kinase kinase 3. Mol Biol Cell 14(2):529-544

Ekman M, Mu Y, Lee SY, Edlund S, Kozakai T, Thakur N, Tran H, Qian J, Groeden J, Heldin CH et al (2012) APC and Smad7 link TGFbeta type I receptors to the microtubule system to promote cell migration. Mol Biol Cell 23:2109-2121

Epstein JB, Gorsky M, Guglietta A, Le N, Sonis ST (2000) The correlation between epidermal growth factor levels in saliva and the severity of oral mucositis during oropharyngeal radiation therapy. Cancer 89:2258-2265

Epstein JB, Silverman S Jr, Paggiarino DA, Crockett S, Schubert MM, Senzer NN, Lockhart PB, Gallagher MJ, Peterson DE, Leveque FG (2001) Benzydamine $\mathrm{HCl}$ for prophylaxis of radiation-induced oral mucositis: results from a multicenter, randomized, double-blind, placebo-controlled clinical trial. Cancer 92:875-885

Feng XH, Derynck R (2005) Specificity and versatility in tgf-beta signaling through Smads. Annu Rev Cell Dev Biol 21:659-693

Groneberg DA, Witt H, Adcock IM, Hansen G, Springer J (2004) Smads as intracellular mediators of airway inflammation. Exp Lung Res 30:223-250

Halder SK, Beauchamp RD, Datta PK (2005) Smad7 induces tumorigenicity by blocking TGF-beta-induced growth inhibition and apoptosis. Exp Cell Res 307:231-246

Han G, Li F, Ten Dijke P, Wang XJ (2011) Temporal smad7 transgene induction in mouse epidermis accelerates skin wound healing. Am J Pathol 179:1768-1779

Han G, Bian L, Li F, Cotrim A, Wang D, Lu J, Deng Y, Bird G, Sowers A, Mitchell JB et al (2013) Preventive and therapeutic effects of Smad7 on radiation-induced oral mucositis. Nat Med 19:421-428

Hayashi H, Abdollah S, Qiu Y, Cai J, Xu YY, Grinnell BW, Richardson MA, Topper JN, Gimbrone MA Jr, Wrana JL et al (1997) The MAD-related protein Smad7 associates with the TGFbeta receptor and functions as an antagonist of TGFbeta signaling. Cell 89:1165-1173

He W, Cao T, Smith DA, Myers TE, Wang XJ (2001) Smads mediate signaling of the TGFá superfamily in normal keratinocytes but are lost during skin chemical carcinogenesis. Oncogene 20:471-483

He W, Li AG, Wang D, Han S, Zheng B, Goumans MJ, Ten Dijke P, Wang XJ (2002) Overexpression of Smad7 results in severe pathological alterations in multiple epithelial tissues. EMBO $\mathrm{J}$ 21:2580-2590

Henke M, Alfonsi M, Foa P, Giralt J, Bardet E, Cerezo L, Salzwimmer M, Lizambri R, Emmerson L, Chen MG et al (2011) Palifermin decreases severe oral mucositis of patients undergoing postoperative radiochemotherapy for head and neck cancer: a randomized, placebo-controlled trial. J Clin Oncol 29:2815-2820

Hong S, Lim S, Li AG, Lee C, Lee YS, Lee EK, Park SH, Wang XJ, Kim SJ (2007) Smad7 binds to the adaptors TAB2 and TAB3 to block recruitment of the kinase TAK1 to the adaptor TRAF2. Nat Immunol 8:504-513 
Javelaud D, Delmas V, Moller M, Sextius P, Andre J, Menashi S, Larue L, Mauviel A (2005) Stable overexpression of Smad7 in human melanoma cells inhibits their tumorigenicity in vitro and in vivo. Oncogene 24:7624-7629

Jyung RW, Wu L, Pierce GF, Mustoe TA (1994) Granulocytemacrophage colony-stimulating factor and granulocyte colonystimulating factor: differential action on incisional wound healing. Surgery 115:325-334

Kavsak P, Rasmussen RK, Causing CG, Bonni S, Zhu H, Thomsen GH, Wrana JL (2000) Smad7 binds to Smurf2 to form an E3 ubiquitin ligase that targets the TGFbeta receptor for degradation. Mol Cell 6:1365-1375

Khuntia D, Harris J, Bentzen SM, Kies MS, Meyers JN, Foote RL, Machtay M, Straube WL (2008) Increased oral mucositis after IMRT versus non-IMRT when combined with cetuximab and cisplatin or docetaxel for Head and neck cancer: preliminary results of RTOG 0234. Int J Radiat Oncol 72:839

Kim YH, Lee HS, Lee HJ, Hur K, Kim WH, Bang YJ, Kim SJ, Lee KU, Choe KJ, Yang HK (2004) Prognostic significance of the expression of Smad4 and Smad7 in human gastric carcinomas. Ann Oncol 15(4):574-580

Kleeff J, Ishiwata T, Maruyama H, Friess H, Truong P, Buchler MW, Falb D, Korc M (1999) The TGF-beta signaling inhibitor Smad7 enhances tumorigenicity in pancreatic cancer. Oncogene 18:5363-5372

Kulkarni AB, Huh CG, Becker D, Geiser A, Lyght M, Flanders KC, Roberts AB, Sporn MB, Ward JM, Karlsson S (1993) Transforming growth factor beta 1 null mutation in mice causes excessive inflammatory response and early death. Proc Natl Acad Sci USA 90:770-774

Lalla RV, Peterson DE (2006) Treatment of mucositis, including new medications. Cancer J 12:348-354

Lalla RV, Bowen J, Barasch A, Elting L, Epstein J, Keefe DM, McGuire DB, Migliorati C, Nicolatou-Galitis O, Peterson DE et al (2014) MASCC/ISOO clinical practice guidelines for the management of mucositis secondary to cancer therapy. Cancer 120:1453-1461

Lawson CD, Burridge K (2014) The on-off relationship of Rho and Rac during integrin-mediated adhesion and cell migration. Small GTPases 5:e27958

Le QT, Kim HE, Schneider CJ, Murakozy G, Skladowski K, Reinisch S, Chen Y, Hickey M, Mo M, Chen MG et al (2011) Palifermin reduces severe mucositis in definitive chemoradiotherapy of locally advanced head and neck cancer: a randomized, placebocontrolled study. J Clin Oncol 29:2808-2814

Leivonen SK, Ala-Aho R, Koli K, Grenman R, Peltonen J, Kahari VM (2006) Activation of Smad signaling enhances collagenase-3 (MMP-13) expression and invasion of head and neck squamous carcinoma cells. Oncogene 25:2588-2600

Li AG, Lu SL, Zhang MX, Deng C, Wang XJ (2004a) Smad3 knockout mice exhibit a resistance to skin chemical carcinogenesis. Cancer Res 64:7836-7845

Li AG, Wang D, Feng XH, Wang XJ (2004b) Latent TGFbeta1 overexpression in keratinocytes results in a severe psoriasis-like skin disorder. EMBO J 23:1770-1781

Li Q, Zhang D, Wang Y, Sun P, Hou X, Larner J, Xiong W, Mi J (2013) MiR-21/Smad 7 signaling determines TGF-beta1-induced CAF formation. Sci Rep 3:2038
Lin X, Liang M, Feng XH (2000) Smurf2 is a ubiquitin E3 ligase mediating proteasome-dependent degradation of Smad2 in transforming growth factor-beta signaling. $\mathrm{J}$ Biol Chem 275:36818-36822

Liu X, Lee J, Cooley M, Bhogte E, Hartley S, Glick A (2003) Smad7 but not Smad6 cooperates with oncogenic ras to cause malignant conversion in a mouse model for squamous cell carcinoma. Cancer Res 63:7760-7768

Liu IM, Schilling SH, Knouse KA, Choy L, Derynck R, Wang XF (2009) TGFbeta-stimulated Smad1/5 phosphorylation requires the ALK5 L45 loop and mediates the pro-migratory TGFbeta switch. EMBO J 28:88-98

Lu SL, Reh D, Li AG, Woods J, Corless CL, Kulesz-Martin M, Wang XJ (2004) Overexpression of transforming growth factor beta1 in head and neck epithelia results in inflammation, angiogenesis, and epithelial hyperproliferation. Cancer Res 64:4405-4410

Luo X, Ding Q, Wang M, Li Z, Mao K, Sun B, Pan Y, Wang Z, Zang $Y Q$, Chen $Y(2010)$ In vivo disruption of TGF-beta signaling by Smad7 in airway epithelium alleviates allergic asthma but aggravates lung carcinogenesis in mouse. PLoS One 5:e10149

Mallawaarachchi CM, Weissberg PL, Siow RC (2005) Smad7 gene transfer attenuates adventitial cell migration and vascular remodeling after balloon injury. Arterioscler Thromb Vasc Biol 25:1383-1387

Massague J, Gomis RR (2006) The logic of TGFbeta signaling. FEBS Lett 580:2811-2820

Migliorati C, Hewson I, Lalla RV, Antunes HS, Estilo CL, Hodgson B, Lopes NN, Schubert MM, Bowen J, Elad S (2013) Systematic review of laser and other light therapy for the management of oral mucositis in cancer patients. Support Care Cancer 21:333-341

Monteleone G, Pallone F, MacDonald TT (2004) Smad7 in TGFbeta-mediated negative regulation of gut inflammation. Trends Immunol 25:513-517

Nakao A, Afrakhte M, Moren A, Nakayama T, Christian JL, Heuchel R, Itoh S, Kawabata M, Heldin NE, Heldin CH et al (1997) Identification of Smad7, a TGFbeta-inducible antagonist of TGFbeta signalling. Nature 389:631-635

Nicolatou-Galitis O, Sarri T, Bowen J, Di Palma M, Kouloulias VE, Niscola P, Riesenbeck D, Stokman M, Tissing W, Yeoh E et al (2013) Systematic review of anti-inflammatory agents for the management of oral mucositis in cancer patients. Support Care Cancer 21:3179-3189

Park S, Kang JM, Kim SJ, Kim H, Hong S, Lee YJ (2014) Smad7 enhances ATM activity by facilitating the interaction between ATM and Mre11-Rad50-Nbs1 complex in DNA double-strand break repair. Cell Mol Life Sci. doi:10.1007/s00018-014-1687-z

Peterson DE, Ohrn K, Bowen J, Fliedner M, Lees J, Loprinzi C, Mori T, Osaguona A, Weikel DS, Elad S et al (2013) Systematic review of oral cryotherapy for management of oral mucositis caused by cancer therapy. Support Care Cancer 21:327-332

Pittelkow MR, Coffey RJ Jr, Moses HJ (1988) Keratinocytes produce and are regulated by transforming growth factors. Ann NY Acad Sci 548:211-224

Raber-Durlacher JE, von Bultzingslowen I, Logan RM, Bowen J, AlAzri AR, Everaus H, Gerber E, Gomez JG, Pettersson BG, Soga $Y$ et al (2013) Systematic review of cytokines and growth factors for the management of oral mucositis in cancer patients. Support Care Cancer 21:343-355 
Rizzo A, Waldner MJ, Stolfi C, Sarra M, Fina D, Becker C, Neurath MF, Macdonald TT, Pallone F, Monteleone G et al (2011) Smad7 expression in T cells prevents colitis-associated cancer. Cancer Res 71:7423-7432

Rubenstein EB, Peterson DE, Schubert M, Keefe D, McGuire D, Epstein J, Elting LS, Fox PC, Cooksley C, Sonis ST (2004) Clinical practice guidelines for the prevention and treatment of cancer therapy-induced oral and gastrointestinal mucositis. Cancer 100:2026-2046

Saika S, Ikeda K, Yamanaka O, Miyamoto T, Ohnishi Y, Sato M, Muragaki Y, Ooshima A, Nakajima Y, Kao WW et al (2005) Expression of Smad7 in mouse eyes accelerates healing of corneal tissue after exposure to alkali. Am J Pathol 166:14051418

Scully C, Epstein J, Sonis S (2003) Oral mucositis: a challenging complication of radiotherapy, chemotherapy, and radiochemotherapy: part 1, pathogenesis and prophylaxis of mucositis. Head Neck 25:1057-1070

Scully C, Sonis S, Diz PD (2006) Oral mucositis. Oral Dis 12:229241

Shull MM, Ormsby I, Kier AB, Pawlowski S, Diebold RJ, Yin M, Allen R, Sidman C, Proetzel G, Calvin D et al (1992) Targeted disruption of the mouse transforming growth factor-beta 1 gene results in multifocal inflammatory disease. Nature 359:693-699

Singer AJ, Clark RA (1999) Cutaneous wound healing. N Engl J Med 341:738-746

Sonis ST (2002) The biologic role for nuclear factor-kappaB in disease and its potential involvement in mucosal injury associated with anti-neoplastic therapy. Crit Rev Oral Biol Med 13:380389

Sonis ST (2004a) A biological approach to mucositis. J Support Oncol 2:21-32 discussion 35-26

Sonis ST (2004b) The pathobiology of mucositis. Nat Rev Cancer 4:277-284

Sonis ST (2009) Efficacy of palifermin (keratinocyte growth factor-1) in the amelioration of oral mucositis. Core Evid 4:199-205

Sonis ST (2010) Efficacy of palifermin (keratinocyte growth factor-1) in the amelioration of oral mucositis. Core Evid 4:199-205

Sonis ST (2013) Oral mucositis in head and neck cancer: risk, biology, and management. Am Soc Clin Oncol Educ Book. doi: 10.1200/EdBook_AM.2013.33.e236

Sorensen JB, Skovsgaard T, Bork E, Damstrup L, Ingeberg S (2008) Double-blind, placebo-controlled, randomized study of chlorhexidine prophylaxis for 5-fluorouracil-based chemotherapy-induced oral mucositis with nonblinded randomized comparison to oral cooling (cryotherapy) in gastrointestinal malignancies. Cancer 112:1600-1606
Spielberger R, Stiff P, Bensinger W, Gentile T, Weisdorf D, Kewalramani T, Shea T, Yanovich S, Hansen K, Noga $S$ et al (2004) Palifermin for oral mucositis after intensive therapy for hematologic cancers. N Engl J Med 351:2590-2598

Treister N, Sonis S (2008) Oral mucositis. In: Ettingeesr DS (ed) Cancer and drug discovery development: supportive care in cancer therapy. Humana Press, Totowa, pp 193-211

Trotti A, Bellm LA, Epstein JB, Frame D, Fuchs HJ, Gwede CK, Komaroff E, Nalysnyk L, Zilberberg MD (2003) Mucositis incidence, severity and associated outcomes in patients with head and neck cancer receiving radiotherapy with or without chemotherapy: a systematic literature review. Radiother Oncol 66:253-262

Vagliano L, Feraut C, Gobetto G, Trunfio A, Errico A, Campani V, Costazza G, Mega A, Matozzo V, Berni M et al (2011) Incidence and severity of oral mucositis in patients undergoing haematopoietic SCT_results of a multicentre study. Bone Marrow Transplant 46:727-732

Vera-Llonch M, Oster G, Hagiwara M, Sonis S (2006) Oral mucositis in patients undergoing radiation treatment for head and neck carcinoma. Cancer 106:329-336

Wang W, Huang XR, Li AG, Liu F, Li JH, Truong LD, Wang XJ, Lan HY (2005) Signaling mechanism of TGF-beta1 in prevention of renal inflammation: role of Smad7. J Am Soc Nephrol 16:1371-1383

Wang XJ, Han G, Owens P, Siddiqui Y, Li AG (2006) Role of TGF beta-mediated inflammation in cutaneous wound healing. $\mathrm{J}$ Investig Dermatol Symp Proc 11:112-117

Wang J, Zhao J, Chu ES, Mok MT, Go MY, Man K, Heuchel R, Lan HY, Chang Z, Sung JJ et al (2013) Inhibitory role of Smad7 in hepatocarcinogenesis in mice and in vitro. J Pathol 230:441-452

Weigelt C, Haas R, Kobbe G (2011) Pharmacokinetic evaluation of palifermin for mucosal protection from chemotherapy and radiation. Expert Opin Drug Metab Toxicol 7:505-515

Wu HG, Song SY, Kim YS, Oh YT, Lee CG, Keum KC, Ahn YC, Lee SW (2009) Therapeutic effect of recombinant human epidermal growth factor (RhEGF) on mucositis in patients undergoing radiotherapy, with or without chemotherapy, for head and neck cancer: a double-blind placebo-controlled prospective phase 2 multi-institutional clinical trial. Cancer 115:3699-3708

Wu JC, Beale KK, Ma JD (2010) Evaluation of current and upcoming therapies in oral mucositis prevention. Future Oncol 6:1751-1770

Yan X, Chen YG (2011) Smad7: not only a regulator, but also a cross-talk mediator of TGF-beta signalling. Biochem $\mathrm{J}$ 434:1-10

Yarom N, Ariyawardana A, Hovan A, Barasch A, Jarvis V, Jensen SB, Zadik Y, Elad S, Bowen J, Lalla RV (2013) Systematic review of natural agents for the management of oral mucositis in cancer patients. Support Care Cancer 21:3209-3221 